\title{
Association between asthma and serum adiponectin concentration in women
}

\author{
A Sood, ${ }^{1}$ X Cui, ${ }^{1}$ C Qualls, ${ }^{1}$ W S Beckett, ${ }^{2}$ M D Gross, ${ }^{3}$ M W Steffes, ${ }^{3}$ L J Smith, ${ }^{4}$ \\ D R Jacobs $\mathrm{Jr}^{5}$
}

- Further details are published online only at http://thorax.bmj. com/content/vol63/issue10

${ }^{1}$ University of New Mexico Health Sciences Center School of Medicine, Albuquerque, New Mexico, USA; ${ }^{2}$ University of Rochester School of Medicine and Dentistry, Rochester, New York, USA: ${ }^{3}$ University of Minnesota, Minneapolis, Minnesota, USA; ${ }^{4}$ The Feinberg School of Medicine, Northwestern University, Chicago, Illinois, USA;

${ }^{5}$ University of Minnesota, Minneapolis, Minnesota, USA (also affiliated with the University of Oslo, Oslo, Norway)

Correspondence to: Dr A Sood, Division of Pulmonary and Critical Care Medicine, University of New Mexico Health Sciences Center School of

Medicine, Department of Medicine, 1 University of New Mexico, Albuquerque, NM 87131, USA;

asood@salud.unm.edu

Received 19 September 2007 Accepted 16 March 2008 Published Online First 4 April 2008

\section{ABSTRACT}

Background: The association of murine asthma with adiposity may be mediated by adiponectin, an antiinflammatory adipokine with reduced serum concentrations in obese subjects. A study was undertaken to examine whether the serum adiponectin concentration is associated with human asthma and whether it explains the association between adiposity and asthma, particularly in women and in premenopausal women.

Methods: A cross-sectional analysis was performed of 2890 eligible subjects at year 15 of the Coronary Artery Risk Development in Young Adults (CARDIA) cohort and its YALTA ancillary study who had either current asthma or never asthma at that evaluation. Obesity was defined as body mass index (BMI) $\geqslant 30 \mathrm{~kg} / \mathrm{m}^{2}$. Multivariable logistic regression analysis was performed with current asthma status as the dependent variable.

Results: Women, but not men, with current asthma had a lower mean unadjusted serum adiponectin concentration than those with never asthma $(p<0.001$; $p$ for sex interaction $<0.001)$. Similarly, current asthma was related to obesity only in women $(\mathrm{OR} 3.31,95 \% \mathrm{Cl} 2.00$ to 5.46, $p$ for sex interaction $=0.004)$; this association was little affected by adjusting for serum adiponectin. The prevalence of current asthma in premenopausal women was reduced in the highest compared with the lowest tertile of serum adiponectin concentration (OR 0.46, 95\% $\mathrm{Cl} 0.26$ to 0.84, $p=0.03$ ), after adjusting for $\mathrm{BMI}$.

However, the interaction between serum adiponectin concentration and BMI category on current asthma status was not significant in premenopausal women or women overall.

Conclusions: A high serum adiponectin concentration may protect against current asthma in premenopausal women but does not explain the association between asthma and adiposity.

The incidence of obesity is dramatically increasing in the USA and worldwide in both children and adults. ${ }^{1}$ It has recently been shown that adiposity is a risk factor for asthma, particularly in women..$^{2-6}$ Mechanistic explanations that have been advanced to explain this association include mechanical effects (such as lack of tidal stretch leading to latching of airway smooth muscle) and immunological effects of adiposity as well as genetic, hormonal (particularly the effect of female sex hormones) and environmental effects (including change in dietary factors and increased exposure to indoor allergens from increased sedentary habits). ${ }^{7}$

It has been recently shown that adiposity is associated with chronic low-grade systemic inflammation. ${ }^{8}$ This inflammatory state is related to adipokines-proteins mainly produced by adipocytes-which may be pro-inflammatory (such as leptin) or anti-inflammatory (such as adiponectin). Our recent cross-sectional analysis has suggested that high serum concentrations of leptin may be an independent risk factor for asthma in premenopausal women. ${ }^{9}$ Similarly, it has been hypothesised that decreased serum concentrations of adiponectin observed in obese humans may also contribute to the propensity towards asthma in this population. ${ }^{10}$

The study objective was to determine whether the serum adiponectin concentration was associated with asthma and explained the association between adiposity and asthma, particularly in women and in premenopausal women. This was evaluated using the prospective Coronary Artery Risk Development in Young Adults (CARDIA) cohort and its Young Adult Longitudinal Trends in Antioxidants (YALTA) ancillary study. A better understanding of the role of adiponectin in asthma may suggest new ways of treating asthma in the expanding obese population.

\section{METHODS}

\section{Study design}

This is a cross-sectional analysis of the CARDIA and YALTA datasets. This longitudinal epidemiological study focusing on the development of cardiovascular disease risk is funded by the National Heart, Lung, and Blood Institute (NHLBI). During 1985 and 1986 CARDIA recruited 5115 black and white men and women aged 1830 years from four clinical centres in Birmingham (AL), Chicago (IL), Minneapolis (MN) and Oakland (CA) with follow-up examinations completed 2, 5, 7, 10 and 15 years later. At the year 15 examination, 3672 persons were re-examined, constituting nearly $74 \%$ of survivors.

\section{Inclusion and exclusion criteria}

All participants with current or never asthma at the year 15 examination were included. Former asthma, pregnancy, not fasting for $8 \mathrm{~h}$, possible renal disease (men with serum creatinine $>1.8 \mathrm{mg} / \mathrm{dl}$ and women with serum creatinine $>1.5 \mathrm{mg} / \mathrm{dl}$ ) were exclusion criteria. Additionally, those with missing data for independent variables and covariates were excluded from the analysis.

\section{Independent and dependent variables}

Independent variables measured at the year 15 evaluation included standard categories of body mass index (BMI $<18.5 \mathrm{~kg} / \mathrm{m}^{2}$ (underweight); BMI 18.5$24.9 \mathrm{~kg} / \mathrm{m}^{2}$ (normal weight); BMI $25-29.9 \mathrm{~kg} / \mathrm{m}^{2}$ 
(overweight); and $\mathrm{BMI} \geqslant 30 \mathrm{~kg} / \mathrm{m}^{2}$ (obese)), quartiles of waist circumference (which may correlate better with visceral adiposity than global adiposity), as well as three categories (tertiles) of serum adiponectin concentration.

The dependent variable measured at the same time was current asthma status defined as (1) a subject report of taking a medication for asthma at the year 15 evaluation or (2) a selfreported doctor or nurse diagnosis of asthma together with asthma symptoms in the year before the year 15 evaluation. Those who denied taking an asthma medication and a providergiven diagnosis of asthma at all evaluations (years 0, 2, 5, 7, 10 and 15) were classified as never asthma.

\section{Covariates}

The following variables at year 15 were evaluated as covariates: diabetes mellitus, insulin resistance, self-reported smoking status, race, age and physical activity level. These covariates were selected because they have been shown to affect either the asthma status or serum adiponectin concentration. ${ }^{11}{ }^{12}$ Further details about the covariates are available in the online data supplement.

\section{Study measurements}

At the year 15 evaluation, self-reported information was obtained from study subjects using standardised questionnaires. Certified technicians measured height (within $0.5 \mathrm{~cm}$ ), weight (within $0.09 \mathrm{~kg}$ ) and waist circumference (within $0.5 \mathrm{~cm}$ ) using standardised techniques. BMI was defined as weight/height ${ }^{2}$ in $\mathrm{kg} / \mathrm{m}^{2}$. Blood samples were collected after at least $8 \mathrm{~h}$ of fasting. Serum adiponectin levels were measured as part of the YALTA ancillary study by radioimmunoassay at Linco Research (St Charles, Missouri, USA) using a polyclonal antibody raised in a rabbit and purified recombinant adiponectin standards with an effective range of $0.2-40 \mathrm{mg} / \mathrm{l}^{13}$ This assay measures total adiponectin and not the various molecular weight forms of adiponectin. Further details about the study measurements are available in the online data supplement.

\section{Statistical analysis}

Descriptive analyses were performed to calculate frequency distributions, univariate analyses ( $\chi^{2}$ and $t$ tests) were performed for categorical and continuous variables, respectively, and multivariable logistic regression analyses were performed using asthma status (current vs never) as the categorical dependent variable. Consistent with our a priori hypothesis, subgroups defined by sex and menopausal status were examined and formal tests for interaction were performed. Issues of confounding were resolved by including the above-described covariates in the models. A two-sided $p$ value of $<0.05$ was considered statistically significant. All statistical analysis was done using the SAS package Version 9.1. This study was approved by the University of New Mexico Human Research Review Committee, Albuquerque, NM, USA.

\section{RESULTS}

Among the 3672 participants in the CARDIA year 15 evaluation, 424 met the exclusion criteria, including 404 participants with former asthma. An additional 358 participants were excluded either because of missing serum adiponectin values $(n=317)$ or missing covariates $(n=41)$. Of the 2890 eligible participants whose data were analysed, 246 had current asthma and 2644 had never asthma. This population included 1603 women (55\%). Of the 1554 women for whom these data were available, 1391 (90\%) were premenopausal. As shown in table 1, participants with current asthma had significantly higher mean BMI, waist circumference and insulin resistance, lower mean values of forced expiratory volume in $1 \mathrm{~s} /$ forced vital capacity $\left(\mathrm{FEV}_{1} / \mathrm{FVC}\right.$ ) ratio (obtained 5 years before the year 15 evaluation)

Table 1 Distribution of selected characteristics according to asthma status (all variables assessed at year 15 except where noted)

\begin{tabular}{|c|c|c|c|}
\hline Characteristics & $\begin{array}{l}\text { Current asthma } \\
(\mathrm{n}=246)\end{array}$ & $\begin{array}{l}\text { Never asthma } \\
(\mathrm{n}=2644)\end{array}$ & p Value \\
\hline Mean age (years) & $40.1(3.6)$ & $40.2(3.6)$ & 0.61 \\
\hline Women & $168 / 246(68 \%)$ & $1435 / 2644(54 \%)$ & $<0.001$ \\
\hline Premenopausal women & $132 / 163(81 \%)$ & $1259 / 1391(91 \%)$ & $<0.001$ \\
\hline White race & $119 / 246(48 \%)$ & $1443 / 2644(55 \%)$ & 0.06 \\
\hline Current smokers & $53 / 246(22 \%)$ & $555 / 2644(21 \%)$ & 0.84 \\
\hline Mean $\mathrm{FEV}_{1} / \mathrm{FVC}$ ratio 5 years previously & $0.79(0.18)(n=210)$ & $0.83(0.11)(n=2308)$ & 0.01 \\
\hline Geometric mean physical activity score (exercise units) & $186.4(95 \% \mathrm{Cl} 51.6$ to 672.8$)$ & $221.5(95 \% \mathrm{Cl} 61.5$ to 797.7$)$ & 0.04 \\
\hline History of diabetes mellitus & $21 / 246(9 \%)$ & $141 / 2644(5 \%)$ & 0.04 \\
\hline Geometric mean insulin resistance & $2.9(95 \% \mathrm{Cl} 1.6$ to 5.3$)$ & $2.5(95 \% \mathrm{Cl} 1.3$ to 4.8$)$ & 0.002 \\
\hline Use of cholesterol lowering medication & $9 / 246(4 \%)$ & $60 / 2643(2 \%)$ & 0.17 \\
\hline Mean BMI $\left(\mathrm{kg} / \mathrm{m}^{2}\right)$ & $31.6(8.3)$ & $28.4(6.5)$ & $<0.001$ \\
\hline Men & $28.3(5.3)(n=78)$ & $28.2(5.3)(n=1209)$ & 0.81 \\
\hline Women & $33.2(9.0)(n=168)$ & $28.6(7.4)(n=1435)$ & $<0.001$ \\
\hline Premenopausal women & $32.4(9.2)(n=132)$ & $28.3(7.2)(n=1259)$ & $<0.001$ \\
\hline Mean waist circumference $(\mathrm{cm})$ & $93.8(16.1)$ & $88.9(14.8)$ & $<0.001$ \\
\hline Men & $93.6(12.7)(n=78)$ & $93.8(13.1)(n=1209)$ & 0.91 \\
\hline Women & $93.8(17.4)(n=168)$ & $84.8(14.9)(n=1435)$ & $<0.001$ \\
\hline Premenopausal women & $92.3(18.0)(n=132)$ & $84.2(14.7)(n=1259)$ & $<0.001$ \\
\hline Geometric mean serum adiponectin (mg/l) & $8.9(95 \% \mathrm{Cl} 4.9$ to 16.1$)$ & $9.0(95 \% \mathrm{Cl} 4.8$ to 16.8$)$ & 0.77 \\
\hline Men & $8.0(95 \% \mathrm{Cl} 4.5$ to 14.3$)(\mathrm{n}=78)$ & $7.0(95 \% \mathrm{Cl} 3.8$ to 12.9$)(n=1209)$ & 0.06 \\
\hline Women & $9.3(95 \% \mathrm{Cl} 5.1$ to 16.9$)(\mathrm{n}=168)$ & $11.1(95 \% \mathrm{Cl} 6.3$ to 19.3$)(\mathrm{n}=1435)$ & $<0.001$ \\
\hline Premenopausal women & $9.8(95 \% \mathrm{Cl} 5.7$ to 16.8$)(\mathrm{n}=132)$ & $11.3(95 \% \mathrm{Cl} 6.5$ to 19.7$)(\mathrm{n}=1259)$ & 0.005 \\
\hline
\end{tabular}

For untransformed variables, the data are expressed as mean (SD) (n); for geometric means the data are expressed as mean (95\% confidence intervals) (n).

The total $n$ value for various comparisons is not uniform because of missing data. The $n$ value for a specific cell is listed in parentheses when it differed from the $n$ value at the top of the column.

$\mathrm{BMI}$, body mass index; $\mathrm{FEV}_{1}$, forced expiratory volume in $1 \mathrm{~s}$; FVC, forced vital capacity. 
Table 2 Association between risk for current asthma and adiposity with and without adjustment for serum adiponectin concentration

\begin{tabular}{|c|c|c|c|c|}
\hline \multirow[b]{2}{*}{ Models for adiposity measure } & \multicolumn{2}{|l|}{ Women } & \multicolumn{2}{|l|}{ Men } \\
\hline & $\begin{array}{l}\text { No with current } \\
\text { asthma/total }\end{array}$ & OR (95\% CI) & $\begin{array}{l}\text { No with current } \\
\text { asthma/total }\end{array}$ & OR (95\% Cl) \\
\hline \multicolumn{5}{|l|}{ BMI } \\
\hline Underweight and normal weight & $31 / 585$ & 1 & $18 / 356$ & 1 \\
\hline Overweight & $37 / 420$ & $1.68(1.01$ to 2.79$)$ & $39 / 559$ & $1.54(0.84$ to 2.80$)$ \\
\hline Obese & $100 / 598$ & $3.31(2.00$ to 5.46$)$ & $21 / 372$ & $1.33(0.61$ to 2.89$)$ \\
\hline $\mathrm{p}$ Value for Wald $\chi^{2}$ & $<0.001$ & & 0.37 & \\
\hline \multicolumn{5}{|l|}{ BMI adjusted for adiponectin } \\
\hline Underweight and normal weight & $31 / 585$ & 1 & $18 / 356$ & 1 \\
\hline Overweight & $37 / 420$ & $1.63(0.98$ to 2.74$)$ & $39 / 559$ & $1.64(0.89$ to 3.02$)$ \\
\hline Obese & $100 / 598$ & $3.19(1.91$ to 5.32$)$ & $21 / 372$ & $1.45(0.66$ to 3.17$)$ \\
\hline $\mathrm{p}$ Value for Wald $\chi^{2}$ & $<0.001$ & & 0.28 & \\
\hline \multicolumn{5}{|c|}{$\begin{array}{l}\text { Covariates adjusted in each logistic regression model include age, race, smoking status, In(physical activity), history of diabetes and } \\
\text { In(insulin resistance). In addition, when indicated, group-specific tertiles of serum adiponectin concentration were also adjusted. } \\
\text { The interaction between sex and BMl on current asthma was significant ( } \mathrm{p}=0.004 \text { in both models). } \\
\text { Adiponectin tertile cut-off points are } 1.2-9.0,9.0-14.4 \text { and } 14.4-94.8 \mathrm{mg} / \mathrm{l} \text { for women and } 1.0-6.0,6.0-9.6 \text { and } 9.6-64.0 \mathrm{mg} / \mathrm{l} \text { for men. } \\
\text { Similar results were obtained when the underweight and normal weight categories were analysed separately with the latter serving } \\
\text { as the referent category. } \\
\text { BMl categories are defined as follows: underweight }<18.5 \mathrm{~kg} / \mathrm{m}^{2} \text {; normal weight } 18.5-24.9 \mathrm{~kg} / \mathrm{m}^{2} \text {; overweight } 25.0-29.9 \mathrm{~kg} / \mathrm{m}^{2} \text {; } \\
\text { obese } \geqslant 30 \mathrm{~kg} / \mathrm{m}^{2} \text {. } \\
\text { BMl, body mass index; } \mathrm{Cl} \text {, confidence interval; OR, odds ratio. }\end{array}$} \\
\hline
\end{tabular}

and were more likely to be women and diabetic than those with never asthma ( $p$ values for all comparisons $<0.05$ ).

As has been shown previously, the serum adiponectin concentration correlated better with waist circumference than with BMI (Spearman correlation coefficients -0.42 and -0.31 , respectively). ${ }^{11}$ Women had higher mean serum adiponectin concentrations than men (geometric means $10.9 \mathrm{mg} / \mathrm{l}$ vs $7.1 \mathrm{mg} / \mathrm{l} ; \mathrm{p}<0.001)$. Among women, premenopausal women had a higher mean serum adiponectin concentration than postmenopausal women (geometric mean $11.2 \mathrm{mg} / \mathrm{l}$ vs $8.9 \mathrm{mg} / \mathrm{l}$; $\mathrm{p}<0.001)$. Although there was no difference in mean serum adiponectin concentrations between the current asthma and never asthma groups in men and women combined, women with current asthma had lower mean serum adiponectin concentrations than women with never asthma (geometric means $9.3 \mathrm{mg} / 1$ vs $11.1 \mathrm{mg} / \mathrm{l} ; \mathrm{p}<0.001$, table 2). This association between current asthma and low serum adiponectin concentration was not seen in men ( $p$ for interaction between sex and serum adiponectin in estimation of current asthma <0.001).

Since this population included only 42 underweight participants $(1 \%)$ and since the initial evaluation showed a linear and not a bowl-shaped relationship between BMI categories and asthma risk, underweight and normal weight subjects were combined to form the referent category for subsequent analyses in tables 2 and 4. As shown in table 2, current asthma was associated with overweight and obese status for women with odds ratios (ORs) of 1.68 (95\% CI 1.01 to 2.79 ) and of 3.31 (95\% CI 2.00 to 5.46), respectively. The formal test for interaction between sex and BMI category in the estimation of current asthma was significant $(p=0.004)$. Similarly, current asthma was associated with the third and fourth quartiles of waist circumference for women with ORs of 2.58 (95\% CI 1.52 to 4.38 ) and 3.09 (95\% CI 1.77 to 5.37), respectively (see expanded table 2 in online data supplement). The formal test for interaction between sex and waist circumference category in the estimation of current asthma was similarly significant $(p=0.02)$. However, the association between the risk for current asthma and adiposity (BMI or waist circumference) was not affected by adjusting for the serum adiponectin concentration in women. Similar results were obtained when the analysis was limited to premenopausal women alone (see expanded table 2 in online data supplement).

Since the associations between adiposity and asthma (table 2) and between serum adiponectin and asthma (table 1) were seen only in women and since most women in this study were premenopausal (90\%), further analyses in tables 3 and 4 were focused on premenopausal women. Analyses relating to all women and men are presented in expanded tables 3 and 4 in the online data supplement. Uniform adiponectin cut-off points generated from the premenopausal group were used for these analyses.

Table 3 Association between current asthma status and serum adiponectin concentration in premenopausal women, with and without adjusting for adiposity

\begin{tabular}{lll}
\hline & \multicolumn{2}{c}{ Premenopausal women } \\
\cline { 2 - 3 } & $\begin{array}{l}\text { No with current } \\
\text { asthma/total }\end{array}$ & OR (95\% CI) \\
\hline Adiponectin & & \\
$1^{\text {st }}$ tertile & $62 / 495$ & 1 \\
$2^{\text {nd }}$ tertile & $51 / 487$ & $0.87(0.57$ to 1.33$)$ \\
$3^{\text {rd }}$ tertile & $19 / 409$ & $0.38(0.21$ to 0.69$)$ \\
$\mathrm{p}$ Value for Wald $\chi^{2}$ & 0.004 & \\
& & \\
Adiponectin adjusted for BMI & & \\
$1^{\text {st }}$ tertile & $62 / 495$ & 1 \\
$2^{\text {nd }}$ tertile & $51 / 487$ & $0.93(0.61$ to 1.42$)$ \\
$3^{\text {rd }}$ tertile & $19 / 409$ & $0.46(0.26$ to 0.84$)$ \\
$\mathrm{p}$ Value for Wald $\chi^{2}$ & 0.03 & \\
\hline
\end{tabular}

Covariates adjusted in each logistic regression model include age, race, smoking status, In(physical activity), history of diabetes and In(insulin resistance).

Adiponectin tertile cut-off points used in the above analysis were derived from premenopausal women (1.2-9.0, 9.0-15.0 and 15.0-94.8 mg/l).

When the third tertile of adiponectin was further split into two halves, the more extreme half had the lowest odds ratio. Similar trends were obtained when In (adiponectin) was used as a continuous (instead of categorical) independent variable in the above analysis.

$\mathrm{BMI}$, body mass index; $\mathrm{Cl}$, confidence interval; $\mathrm{OR}$, odds ratio. 
Table 3 shows that a high serum adiponectin concentration was associated with reduced odds of current asthma in premenopausal women. After adjusting for BMI and other covariates, the highest tertile of serum adiponectin concentration in premenopausal women was associated with reduced odds of current asthma with an OR of 0.46 (95\% CI 0.26 to $0.84)$ compared with the lowest tertile $(p=0.03)$. Similar results were obtained after adjusting for waist circumference in the analysis instead of BMI (see expanded table 3 in online data supplement).

The interaction between menopausal status and serum adiponectin category on current asthma status in women was not significant (the range of $\mathrm{p}$ values in the unadjusted pairwise comparisons was $0.32-0.92$, see expanded table 3 in online supplement). However, this analysis was limited by the small number of participants in the postmenopausal group $(n=163)$.

A stratified analysis suggested that the OR of the association between current asthma and obese status may be highest in those with the lowest tertile of serum adiponectin concentration, both in premenopausal women and in women overall (see table 4 and expanded table 4 in online data supplement), although the formal test of interaction between BMI and adiponectin in the estimation of current asthma was not statistically significant in either group (the range of $p$ values in the unadjusted pairwise comparisons was 0.45-0.99). Similar results were obtained after adjusting for waist circumference in the analysis instead of BMI (data not shown).

\section{DISCUSSION}

This study demonstrates three possible and important results. First, a lower serum adiponectin concentration is associated with current asthma only in women in an unadjusted analysis.

Table 4 Stratified analysis of the association between current asthma and BMI categories in premenopausal women according to tertiles of serum adiponectin concentration

\begin{tabular}{|c|c|c|c|}
\hline \multirow[b]{2}{*}{$\begin{array}{l}\text { Tertiles of } \\
\text { adiponectin }\end{array}$} & \multirow[b]{2}{*}{ BMI category } & \multicolumn{2}{|c|}{ Premenopausal women } \\
\hline & & $\begin{array}{l}\text { No with current } \\
\text { asthma/total }\end{array}$ & OR (95\% Cl) \\
\hline \multirow[t]{4}{*}{ Tertile 1} & $\begin{array}{l}\text { Underweight and normal } \\
\text { weight }\end{array}$ & $5 / 88$ & 1 \\
\hline & Overweight & $10 / 130$ & 1.82 (0.58 to 5.72$)$ \\
\hline & Obese & $47 / 277$ & 5.77 (1.96 to 17.01$)$ \\
\hline & $\mathrm{p}$ Value for Wald $\chi^{2}$ & 0.001 & \\
\hline \multirow[t]{4}{*}{ Tertile 2} & $\begin{array}{l}\text { Underweight and normal } \\
\text { weight }\end{array}$ & $15 / 186$ & 1 \\
\hline & Overweight & $14 / 145$ & 1.21 (0.56 to 2.62 ) \\
\hline & Obese & $22 / 156$ & 1.93 (0.87 to 4.24$)$ \\
\hline & $\mathrm{p}$ Value for Wald $\chi^{2}$ & 0.24 & \\
\hline \multirow[t]{4}{*}{ Tertile 3} & $\begin{array}{l}\text { Underweight and normal } \\
\text { weight }\end{array}$ & $8 / 259$ & 1 \\
\hline & Overweight & $8 / 98$ & $2.30(0.80$ to 6.63$)$ \\
\hline & Obese & $3 / 52$ & $1.11(0.24$ to 5.14$)$ \\
\hline & $\mathrm{p}$ Value for Wald $\chi^{2}$ & 0.26 & \\
\hline
\end{tabular}

All models were adjusted for age, race, smoking status, In(physical activity), history of diabetes and In(insulin resistance).

The interactions between BMI categories and serum adiponectin on current asthma status were not significant $(p=0.45)$. Similar results were obtained when BMI and In(adiponectin) were used as continuous variables $(p=0.75)$.

Adiponectin tertile cut-off points used in the above analysis were derived from premenopausal women (1.2-9.0, 9.0-15.0 and 15.0-94.8 mg/l).

Similar results were obtained when the underweight and normal weight categories were analysed separately with the latter serving as the referent category.

BMI categories are defined as follows: underweight $<18.5 \mathrm{~kg} / \mathrm{m}^{2}$; normal weight

$18.5-24.9 \mathrm{~kg} / \mathrm{m}^{2}$; overweight $25.0-29.9 \mathrm{~kg} / \mathrm{m}^{2}$; obese $\geqslant 30 \mathrm{~kg} / \mathrm{m}^{2}$.

$\mathrm{BMI}$, body mass index; $\mathrm{Cl}$, confidence interval; $\mathrm{OR}$, odds ratio.
Second, the serum adiponectin concentration does not appear to explain the association between adiposity and asthma in women. Third, a high serum adiponectin concentration may be associated with reduced odds of asthma in premenopausal women, an effect that may be independent of adiposity. In addition, we confirm the results from other studies showing that asthma is associated with adiposity only in women.

In 2005 more than 21 million people in the USA were estimated to be affected by asthma, amounting to $7.6 \%$ of the total population. ${ }^{14}$ Between 1980 and 1996 the prevalence of and morbidity trends related to asthma increased in the USA. ${ }^{15}$ In parallel with the rise in the prevalence of asthma, there has been a rise in the prevalence of obesity in the USA. ${ }^{1}$ In 1999-2002, $65.1 \%$ of adults in the USA were either overweight or obese and $30.4 \%$ were obese. ${ }^{16}$ The somewhat contemporaneous course of the two epidemics has sparked interest in adiposity as a risk factor for asthma. Some (but not all) studies have also shown that adiposity is a stronger risk factor for asthma in women than in men. ${ }^{2-6}$

Adipose tissue produces and releases a variety of proinflammatory and anti-inflammatory factors. ${ }^{17}$ Some of these substances may play a role in the development of a number of inflammatory conditions such as cardiovascular disease, type 2 diabetes and possibly asthma, although their pathogenic role is far from proven. One of the anti-inflammatory adipokines is adiponectin. Although central (visceral) adipocytes are the most important source of adiponectin, ${ }^{11}$ the serum adiponectin concentration does not increase with obesity in the way the serum leptin concentration does. On the contrary, there is a tendency for a reduced serum adiponectin concentration in obese subjects. ${ }^{18}$

Obesity is associated with high rates of necrosis of adipocytes, exposing naked lipid droplets to the interstitium. ${ }^{19}$ Macrophages gather round the necrosing adipocytes and become functionally activated, forming syncytia. ${ }^{19}$ Macrophages in the adipose tissue produce tumour necrosis factor $\alpha(\mathrm{TNF} \alpha)$ and interleukin 6 (IL6) which, in turn, may directly inhibit the local production of adiponectin in a paracrine fashion. ${ }^{20}$ This may explain the reduced systemic adiponectin concentration seen in obesity.

The anti-inflammatory properties of adiponectin include inhibition of pro-inflammatory cytokines such as TNF $\alpha$ and IL- $6^{21} 22$ and endothelial adhesion molecules such as intercellular adhesion molecule (ICAM)-1, vascular cell adhesion molecule (VCAM)-1 and P-selectin ${ }^{23}$ as well as induction of antiinflammatory cytokines such as IL-10 and IL-1 receptor antagonist. 22425 Adiponectin may therefore modulate the activation, proliferation, cytotoxicity and cytokine production by inflammatory cells as well as affect interactions of $\mathrm{T}$ cells with other T cells, target cells and B cells. Since ICAM-1 is the receptor for most rhinoviruses (the most important cause of asthma exacerbations) ${ }^{26}$ and P-selectin-mediated adhesion of leucocytes to the vascular endothelium is a key early event in the initiation of the inflammatory response, it is conjectured that the effects of adiponectin on endothelial adhesion molecules may play a role in asthma causation. In addition, adiponectin inhibits proliferation and migration of cultured vascular smooth muscle cells induced by mitogens ${ }^{27-29}$ and may have similar effects on murine airway smooth muscle (fig 1). ${ }^{10}$ Given that adiponectin receptors are expressed in cultured human airway smooth cells, ${ }^{30}$ it has been hypothesised that a decline in serum adiponectin concentration in obese subjects may contribute to the increased airway smooth muscle mass seen with remodelling in chronic asthma. ${ }^{31}$ 


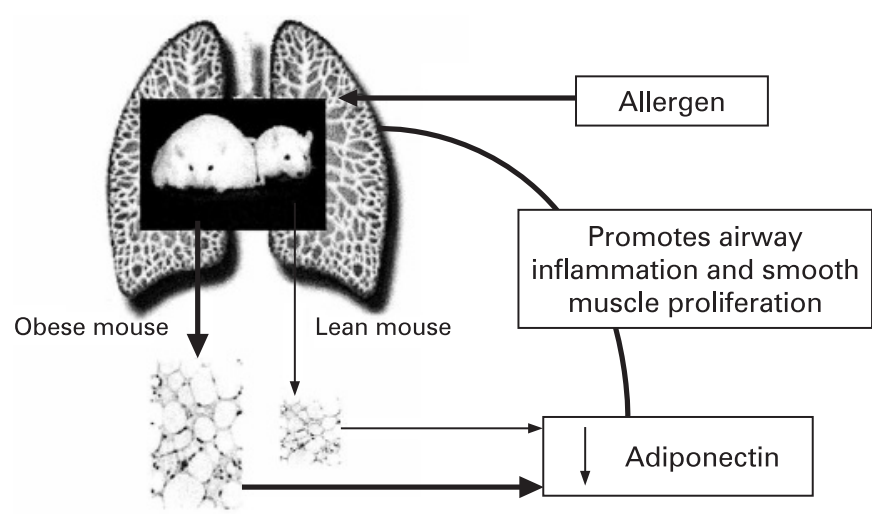

Adipose tissue*

Figure 1 Schematic representation of the suggested role of adiponectin in murine asthma based on work by Shore et al. ${ }^{10} 3031{ }^{*}$ Adipocytes and stromal macrophages are both hypertrophic and hyperplastic in obese mice compared with lean mice.

Murine models have also shown that subcutaneous injection of adiponectin in ovalbumin-sensitised mice prevents the subsequent development of increased airway responsiveness on exposure to ovalbumin. ${ }^{10} 31$ Taken together, the known antiinflammatory effects of adiponectin in both mice and humans and the prevention of both allergen-induced airway responsiveness and airway smooth muscle proliferation in murine models has led to the hypothesis that the decreased serum concentrations of adiponectin in obese humans may contribute to the propensity towards asthma in this population. ${ }^{30}$

This study suggests that a higher serum adiponectin concentration may be a protective factor for current asthma in women, particularly those who are premenopausal. The observed association was independent of adiposity. These results are consistent with a previous cross-sectional study from a different population that suggested that high serum concentrations of leptin, another adipokine, are an independent risk factor for asthma in premenopausal women and that this effect may also be independent of adiposity. ${ }^{9}$ These results suggest that there may be interplay between female sex hormones, selected adipokines and asthma, although this remains to be proven.

Despite the strong biological plausibility cited above, this study fails to show convincingly that the serum adiponectin concentration modifies the association between adiposity and asthma. There are three possible explanations. First, human asthma and murine asthma have different pathophysiological pathways $^{32}$ and therefore adiponectin may not play the same pathogenic role in the association between adiposity and human asthma as it does in the murine asthma model. Second, human cross-sectional studies may not be able to show clear associations because of the presence of multiple confounding factors and the lack of knowledge of temporal sequencing of the variables. For instance, it may be necessary to replicate the mouse intervention study design in human subjects in order to better understand the role of adiponectin on the human airway. This may be possible by studying either the effect of factors that affect serum adiponectin (such as exercise, weight reduction and peroxisome proliferator-activated receptor $\gamma$ agonists) on asthma outcome measures or the effect of specific allergen inhalation on serum adiponectin concentrations in subjects with asthma. Third and most important, it is likely that the association between adiposity and a complex disease trait such as asthma is mediated not by one adipokine but a balance of several pro-inflammatory and anti-inflammatory adipokines, and that adiponectin is only a part of the larger puzzle. On the same line of reasoning, it is possible that other mechanistic pathways such as the mechanical effect of adiposity and genetic, hormonal and environmental pathways are more important than the immunological effects of adiposity in the association between asthma and adiposity in humans.

The strengths of the study include its relatively large sample size and its clinical translational character, based on the recently published data on the role of adiponectin in asthma in the mouse model by Shore et al..$^{10} 11$ The study, however, has some limitations. The asthma diagnosis was self-reported and this may result in misclassification bias, particularly among obese subjects. ${ }^{33}$ Further, this is an observational cross-sectional study which can only allow for hypothesis generation but does not prove causality or the direction of causation. The number of postmenopausal subjects in this relatively young cohort is small (about 10\%), making it difficult to compare with premenopausal women. In addition, the observed lack of association in men may be due to a relatively smaller number of people with asthma among men than women, rather than a true lack of association. Further, in order to confirm definitively that adiponectin has a different effect on asthma status in various groups, a statistically significant interaction is required. This exploratory analysis lacks the power to detect a statistically significant interaction. Finally, adiponectin is present in serum in hexameric low molecular weight and multimeric high molecular weight forms which were not separately measured in this study. Debate exists as to whether the various forms have the same in vivo activity. ${ }^{34}$

In summary, a high serum adiponectin concentration may exert a protective effect against asthma in premenopausal women and this effect may be independent of adiposity. However, the association between adiposity and asthma seen among women in the CARDIA study cannot be explained by the serum adiponectin concentration. Future studies will need to expand on these observations to improve our understanding of the association between asthma and adiposity. A better understanding of the role of adiponectin in asthma may suggest newer ways of treating asthma in obese subjects.

Funding: AS is supported by the University of New Mexico Clinical Translational Science Center Scholar Award and DHHS/NIH/NCRR/GCRC Grant \# 5M01 RR00997; WSB is supported by ES01247; MWS has several grants/contracts from NIDDK, NHLBI and NICHD. The Coronary Artery Risk Development in Young Adults Study is conducted and supported by the National Heart, Lung, and Blood Institute (NHLBI) in collaboration with the Coronary Artery Risk Development in Young Adults Study Investigators.

\section{Competing interests: None.}

Ethics approval: This study was approved by the University of New Mexico Human Research Review Committee, Albuquerque, NM, USA.

\section{REFERENCES}

1. Kuczmarski RJ, Carroll MD, Flegal KM, et al. Varying body mass index cutoff points to describe overweight prevalence among US adults: NHANES III (1988-1994). Obes Res 1997;5:542-8.

2. Beckett WS, Jacobs DR Jr, Yu X, et al. Asthma is associated with weight gain in females but not males, independent of physical activity. Am J Respir Crit Care Med 2001;164:2045-50.

3. Celedon JC, Palmer LJ, Litonjua AA, et al. Body mass index and asthma in adults in families of subjects with asthma in Anqing, China. Am J Respir Crit Care Med 2001;164(10 Pt 1):1835-40.

4. Castro-Rodriguez JA, Holberg CJ, Morgan WJ, et al. Increased incidence of asthmalike symptoms in girls who become overweight or obese during the school years. Am J Respir Crit Care Med 2001;163:1344-9.

5. Figueroa-Munoz JI, Chinn S, Rona RJ. Association between obesity and asthma in 4-11 year old children in the UK. Thorax 2001;56:133-7.

6. Camargo CA Jr, Weiss ST, Zhang S, et al. Prospective study of body mass index, weight change, and risk of adult- onset asthma in women. Arch Intern Med 1999;159:2582-8. 
7. Sood A. Does obesity weigh heavily on the health of the human airway? J Allergy Clin Immunol 2005;115:921-4.

8. Takahashi K, Mizuarai S, Araki H, et al. Adiposity elevates plasma MCP-1 levels leading to the increased CD11b-positive monocytes in mice. J Biol Chem 2003;278:46654-60.

9. Sood A, Camargo Jr CA, Ford ES. Association between leptin and asthma in adults. Thorax 2006;61:300-5.

10. Shore SA, Terry RD, Flynt $L$, et al. Adiponectin attenuates allergen-induced airway inflammation and hyperresponsiveness in mice. J Allergy Clin Immunol 2006:118:389-95.

11. Steffes MW, Gross MD, Schreiner PJ, et al. Serum adiponectin in young adults: interactions with central adiposity, circulating levels of glucose, and insulin resistance: the CARDIA study. Ann Epidemiol 2004;14:492-8.

12. Platts-Mills TA, Carter MC, Heymann PW. Specific and nonspecific obstructive lung disease in childhood: causes of changes in the prevalence of asthma. Environ Health Perspect 2000:108(Suppl 4):725-31.

13. Cnop M, Havel PJ, Utzschneider KM, et al. Relationship of adiponectin to body fat distribution, insulin sensitivity and plasma lipoproteins: evidence for independent roles of age and sex. Diabetologia 2003;46:459-69.

14. Centers for Disease Control and Prevention. National Health Interview Survey, 2001-2005. 2005.

15. Centers for Disease Control and Prevention. Self-reported asthma prevalence among adults-United States, 2000. JAMA 2001;286:1571-2.

16. Hedley AA, Ogden CL, Johnson $\mathrm{CL}$, et al. Prevalence of overweight and obesity among US children, adolescents, and adults, 1999-2002. JAMA 2004;291:2847-50.

17. Fantuzzi G. Adipose tissue, adipokines and inflammation. J Allergy Clin Immunol 2005;115:911-20.

18. Arita $\mathbf{Y}$, Kihara S, Ouchi N, et al. Paradoxical decrease of an adipose-specific protein, adiponectin, in obesity. Biochem Biophys Res Commun 1999;257:79-83.

19. Cinti S, Mitchell G, Barbatelli G, et al. Adipocyte death defines macrophage localization and function in adipose tissue of obese mice and humans. J Lipid Res 2005:46:2347-55.
20. Bruun JM, Lihn AS, Verdich C, et al. Regulation of adiponectin by adipose tissuederived cytokines: in vivo and in vitro investigations in humans. Am J Physiol Endocrinol Metab 2003;285:E527-33.

21. Masaki T, Chiba S, Tatsukawa H, et al. Adiponectin protects LPS-induced liver injury through modulation of TNF-alpha in KK-Ay obese mice. Hepatology 2004;40:177-84.

22. Wulster-Radcliffe MC, Ajuwon KM, Wang J, et al. Adiponectin differentially regulates cytokines in porcine macrophages. Biochem Biophys Res Commun 2004;316:924-9.

23. Kougias $\mathbf{P}$, Chai $\mathrm{H}$, Lin PH, et al. Effects of adipocyte-derived cytokines on endothelial functions: implication of vascular disease. J Surg Res 2005;126:121-9.

24. Kumada M, Kihara S, Ouchi N, et al. Adiponectin specifically increased tissue inhibitor of metalloproteinase-1 through interleukin-10 expression in human macrophages. Circulation 2004;109:2046-9.

25. Wolf AM, Wolf D, Rumpold $\mathrm{H}$, et al. Adiponectin induces the anti-inflammatory cytokines IL-10 and IL-1RA in human leukocytes. Biochem Biophys Res Commun 2004:323:630-5.

26. Stanciu LA, Djukanovic R. The role of ICAM-1 on T-cells in the pathogenesis of asthma. Eur Respir J 1998;11:949-57.

27. Kondo H, Shimomura I, Matsukawa Y, et al. Association of adiponectin mutation with type 2 diabetes: a candidate gene for the insulin resistance syndrome. Diabetes 2002:51:2325-8.

28. Okamoto $\mathbf{Y}$, Kihara $\mathrm{S}$, Ouchi $\mathrm{N}$, et al. Adiponectin reduces atherosclerosis in apolipoprotein E-deficient mice. Circulation 2002;106:2767-70.

29. Ouchi N, Kihara S, Arita Y, et al. Novel modulator for endothelial adhesion molecules: adipocyte-derived plasma protein adiponectin. Circulation 1999;100:2473-6.

30. Shore SA, Johnston RA. Obesity and asthma. Pharmacol Ther 2006;110:83-102.

31. Shore SA. Obesity and asthma: cause for concern. Curr Opin Pharmacol 2006:6:230-6.

32. Wenzel S, Holgate ST. The mouse trap: it still yields few answers in asthma Am J Respir Crit Care Med 2006:174:1173-8.

33. Schachter LM, Salome CM, Peat JK, et al. Obesity is a risk for asthma and wheeze but not airway hyperresponsiveness. Thorax 2001;56:4-8.

34. Kobayashi H, Ouchi N, Kihara S, et al. Selective suppression of endothelial cell apoptosis by the high molecular weight form of adiponectin. Circ Res 2004;94:e27-31.

\section{Lung alert}

\section{A novel approach to preventing adolescent smoking in schools}

Addiction can occur rapidly in young smokers with consequent health problems in later life. Valuable resources are wasted when school interventions are ineffective, underscoring the need for evidence-based interventions. Approaches are often school-based owing to consistent access to students, with peer-led programmes proposed as a way forward.

This cluster randomised controlled trial targeted children aged 12-13 years, aiming to spread non-smoking behaviour in schools with peer help but in a hitherto uncharted informal out-ofclassroom setting, since a systematic review of peer-led studies that used a conventional classroom-based approach showed variable effectiveness, perhaps contributed to in part by the inevitable loss of credibility when peers adopt formal teaching roles.

A total of 10730 students in 59 schools were randomised to usual smoking education or trial intervention with follow-up being immediately and at 1 and 2 years after randomisation. The primary outcome was smoking in the past week. On intention-to-treat analysis, the odds of smoking at all three follow-up periods were lower in intervention schools, with a significant risk reduction at 1 year that diminished to a non-significant reduction at 2 years. Significance, however, was retained after the planned multilevel modelling to compensate for loss to follow-up.

This robust study with its well planned statistical modelling and encouraging retention rates demonstrates the success of an informal peer-led approach with an effect that seems to last. The importance of the social aspect to smoking shown by this study suggests that other potential vistas may include exploration of the role played by siblings and targeting smoking promotion campaigns.

- Campbell R, Starkey F, Holliday J, et al. An informal school-based peer-led intervention for smoking prevention in adolescence (ASIST): a cluster randomised trial. Lancet 2008;371:1595-602.

\section{N Varun}

Correspondence to: Dr N Varun, Medical Assessment and Admissions Unit, Royal Free Hospital, London, UK; nsvarunkumar@ yahoo.co.in 